\title{
Vegetation classification as a mirror of evolution? Thoughts on the syntaxonomy and management of bramble scrubs of the Prunetalia (Rhamno-Prunetea)
}

\author{
Rense Haveman $^{1,2}$ (1) $\cdot$ Iris de Ronde ${ }^{1}$ \\ Received: 3 October 2018 / Accepted: 25 January 2019 / Published online: 15 March 2019 \\ (C) The Author(s) 2019
}

\begin{abstract}
In Germany and the Netherlands, many bramble scrub associations are distinguished on the basis of the occurrence of Rubus species. The associations belonging to the Prunetalia spinosae Tüxen 1952 are usually assigned to the Pruno-Rubion radulae Weber Osnabr Naturwiss Mitt 3:143-150, 1974, but published tables show inconsistencies in the occurrence of alliance character species. In this paper, we compare synoptic tables from different sources from the Netherlands and Germany. From this comparison, it is concluded that the associations can be divided over two alliances, the Pruno-Rubion radulae in central Europe, and the Pruno-Rubion sprengelii Weber Osnabr Naturwiss Mitt 3:143-150, 1974 in northwest Europe (excluding the UK). The differential species of both these alliances coincide to a considerable degree with the indicator species of the phytogeographical Rubus territories as defined by Haveman et al. (J Biogeogr 43:1360-1371, 2016). As can be deduced from recent molecular studies (Sochor et al. Mol Phylogenet Evol 89:13-27, 2015), these territories have an evolutionary background. This is an effect of the unsaturated distribution areas of a large portion of the very young Rubus agamospecies. The same holds true for the two alliances: although they have a different ecology, we argue that their current distribution areas are not a reflection of this ecology, but both their ecology and distribution area are caused by different evolutionary developments.
\end{abstract}

Keywords Apomicts · Inherited ecology · Pruno-Rubion radulae · Pruno-Rubion sprengelii $\cdot$ Rubus · Vegetation geography · Vegetation history

\section{Introduction}

The Rhamno-Prunetea Rivas Goday et Borja Carbonell ex Tüxen $1962^{1}$ are remarkably rich in taxonomically critical genera, like Crataegus, Rosa and Rubus (especially subgen. Rubus). Of these, Rubus subgen. Rubus is by far the largest, with an

\footnotetext{
${ }^{1}$ We prefer using the long established name Rhamno-Prunetea Rivas Goday \& Borja Carbonell ex Tüxen 1962 over the Crataego-Prunetea Tüxen 1962, contrary to Mucina et al. (2016). The arguments for this choice are given by Weber (1999).
}

Rense Haveman rense.haveman@wur.nl

1 Central Government Real Estate Agency of the Dutch Ministry of the Interior and Kingdom Relations, Expert Centre Technique, Nature Department, P.O. Box 47, 6700, AA Wageningen, The Netherlands

2 Wageningen University and Research, Graduate School for Production Ecology and Resource Conservation, P.O. Box 47, 6700, AA Wageningen, The Netherlands estimated number of species over 1000 in Europe. In the most recent overview in the Atlas Flora Europaea about 700 species are included (Kurtto et al. 2010), but large areas in western Europe are not fully covered, especially France. This country lies in the centre of diversity of the genus, so it might be expected that many new species still have to be discovered and described here. Rubus subgen. Rubus in Europe consists of a polyploid series with only five sexual species, and numerous stabilised pseudogamous lineages (Weber 1995). Already Gustafsson (1942) hypothesised a hybrid origin of the Rubus apomicts, and recent phylogenetical studies have shown that they indeed arose from hybridisation events between only six sexual parental species: Rubus caesius, Rubus canescens, Rubus idaeus, Rubus ulmifolius, and two unknown species, one of subsect. Rubus and one belonging to the series Glandulosi (Sochor et al. 2015). Sochor et al. (2015) hypothesised the Pleistocene climate fluctuations as driver behind the evolution of the subgenus, and a Holocene expansion of the distribution area of the apomicts. Large-scale biogeographical patterns in Rubus subgen. Rubus in western Europe can be explained by 
this hybrid background of the species, as was shown by Haveman et al. (2016): the Rubus flora in the Netherlands and the North-German plain (from here together indicated as the Northwest Continent (NWC) territory, following these authors) is heavily influenced by $R$. ulmifolius, whereas $R$. canescens pressed its stamp on the Rubus flora of Central- and SouthGermany and Denmark (the Southeast Continent (SEC) territory).

Modern phytosociological research on Rubus scrubs had its starting point in the 1960-s, with the publication of Weber's dissertation (1967) on hedgerow communities in SleswigHolstein in North-Germany. In this study, the Rubus rich mesophilous hedgerows of the Prunetalia spinosae Tüxen 1952 were placed in two new associations, viz. the PrunoRubetum vestiti Weber 1967 and the Pruno-Rubetum sprengelii Weber 1967, with the remark that both associations probably better could be considered as separate alliances. In several key-stone publications based on studies by himself and others (Reif 1983; Reif 1985; Rosskamp 1999; Wittig 1976; Wittig 1977), Weber modified this initial scheme by distinguishing more associations and changing the status of the distinguished associations to alliance (the Pruno-Rubion radulae Weber 1974 and the Pruno-Rubion sprengelii Weber 1974 respectively) and later to suballiance level under one alliance, the Pruno-Rubion macrophylli Weber 1981a, a superfluous synonym of the Pruno-Rubion radulae (Weber 1990). According to Weber, the Pruno-Rub(en)ion radulae comprises the bramble scrubs on base rich and nutrient rich soils, whereas the bramble scrubs on slightly acidic and less nutrient rich soils are accommodated in the Pruno-Rub(en)ion sprengelii. Both in the Synopsis (Weber 1999) and in the Pflanzengesellschaften Niedersachsens (Weber in Preising et al. 2003), the scheme with one bramble-rich alliance (i.c. the Pruno-Rubion radulae) with several associations in the Prunetalia was maintained. It was also adopted in the Dutch national vegetation classification, in which two associations and one alliance were distinguished, viz. the Pruno-Rubetum vestiti and the Pruno-Rubetum elegantispinosi Weber 1981a, which are placed in the Pruno-Rubion radulae (Haveman et al. 1999). In the accompanying text, the authors mention the occurrence of the Pruno-Rubetum sprengelii in the Netherlands, but at that time, relevés of this association were lacking completely. In France, Royer (2013) described several new associations which were also placed in the Pruno-Rubion radulae. The thermophilous scrubs of France, which are also found in Spain, Switzerland, Belgium, and probably the southwesternmost part of the Netherlands, are placed in an separate alliance, the Pruno-Rubion ulmifolii Bolós 1954. The Rubus species composition of these thermophilous scrubs have not been explored in detail, which makes their syntaxonomic position unclear; usually they are placed in the Prunetalia next to the Pruno-Rubion radulae (Weber 1974; Weber 1997; Weber 1998b). The Euroveg Checklist recognises only the Pruno-Rubion radulae for the bramble scrubs on neutral and base-rich soils of western and central Europe (Mucina et al. 2016).

Comparing the existing classifications of the mesophilous Rubus scrubs from different regions, there seem to be several problems which were addressed briefly by Haveman et al. (1999) and more in detail by Haveman (2017). The most prominent problem is the apparent incongruence of alliance character species of the Pruno-Rubion radulae in the different regions. In the Synopsis, Weber (1999) mentioned Rubus bifrons, Rubus montanus and Rubus radula as such for Germany, and, additionally in the overview of scrubs in Niedersachsen (Weber in Preising et al. 2003), Rubus goniophorus, Rubus hadracanthos and Rubus orthostachys. These species are lacking almost completely in the Netherlands, and they play no role in the Dutch bramble scrubs. In contrast, here Rubus geniculatus, Rubus lindleianus, and Rubus macrophyllus are frequently occurring, and to a lesser extent also Rubus confusidens, Rubus conspicuus, Rubus egregius, Rubus stereacanthos, and Rubus winteri (Haveman et al. 2017). The underlying cause for this phenomenon might be the relatively small, only partly overlapping distribution areas of many bramble species. Although Haveman (2017) elaborated a little on the effect of this problem on the stability of species combinations over larger areas, it was never studied in detail. In a revision of the Dutch national vegetation overview, Haveman et al. (2017) argued that this difference in species composition between the German and the Dutch Rubus scrubs should be rewarded in the recognition of two separate alliances though, and they again recognised the Pruno-Rubion sprengelii for the Rubus scrubs in the Netherlands. However, this choice was never substantiated with data.

In this paper, we will compare published vegetation tables of mesophilous Rubus scrubs from different regions to answer the question of the tenability of the classification scheme with two alliances - the Pruno-Rubion radulae and the Pruno-Rubion sprengelii - for the accommodation of the Rubus-rich Prunetalia scrubs in north-west and central Europe. The results of this comparison will be evaluated in the framework of the recent evolutionary and biogeographical literature on the genus, to conclude about the underlying causes of the found patterns.

\section{Methods}

The data for the analysis are extracted from the tables published by Haveman et al. (2017) for the Netherlands, Weber (1999) for Germany, and Weber in Preising et al. (2003) for Niedersachsen. Rubus species data for the south German associations included in the Synopsis (Weber 1999), in casu the Pruno-Rubetum bifrontis Weber 1990, are complemented with species mentioned by Oberdorfer and Müller (1992) for the 
Rubo fruticosi-Prunetum spinosae Weber 1974 in the overview table of the Prunetalia in a footnote; these species are in our table mentioned with an 'X'. Likewise, Rubus species which are not present in the tables in the mentioned sources, but nevertheless mentioned in the accompanying texts and footnotes, are included in our analysis. Excluded are pure synantropic communities with introduced species, e.g. with Rubus armeniacus. The synoptic columns or the associations and subassociations based on at least 10 relevés from the mentioned sources are imported and further analysed in Microsoft Excel, resulting in a summarising table with 21 columns. From these original synoptic tables, we included only the phanerogams and hemiphanerogams in our analysis. In the analysis, both columns and species were arranged manually in order to find differential species for groups of synoptic columns, similar to the usual methods used in phytosociology to find differential species in relevé data (Dierschke 1994). In the final table, only the differential species, the alleged syntaxonomically important species, and the species with high frequencies are included, thus resulting in a strongly shortened synoptic table.

The found patterns in this meta-analysis are interpreted in the light of the haplotype data given by Sochor et al. (2015) and the phytogeographical Rubus regions ('territories') by Haveman et al. (2016). For this purpose, each differential (Rubus) species from the former analysis is compared with the Dufrêne-Legendre indicator species of the territories and lower hierarchical levels ('florulae') mentioned by these authors. For each differential species is determined if it was mentioned also as indicator species for the Rubus regions, and if so, for which of the three territories: the British Isles (BI) territory, the NWC territory, or the SEC territory.

\section{Results}

The resulting synoptic table (Table 1) shows two gradients, viz. a geographical one and an ecological one. The first group of communities (column 1-7, group A) is characterised by e.g. $R$. elegantispinosus, $R$. geniculatus, $R$. lindleianus, $R$. macrophyllus, and $R$. winteri. These species define the most western communities from the NWC territory, viz. the North Netherlands, South Netherlands, and Westphälische Bucht florulae (ssu. Haveman et al. 2016). The second group of communities (column 8-13, group B), all belonging to the PrunoRubetum sprengelii, are characterised by Rubus nemoralis, Rubus platyacanthus, Rubus plicatus, Rubus silvaticus, and Rubus sprengelii. These communities are based on relevés from the Deutsches Tiefland florula (ssu. Haveman et al. 2016), which also belongs to the NWC territory. Most of the mentioned species are found also in the more western communities, viz. of the North Netherlands and South Netherlands florulae, and several also in the next group. The last group of communities (column 14-21, group C) is differentiated by Rubus rudis and
R. radula, and several taxa with a low frequency, like $R$. montanus and $R$. hadracanthos. Several of these species are post hoc added to the table on the basis of remarks in the original works, based on phytogeographical studies after the date the relevés were made. In column 14, representing the PrunoRubetum radulae rubetosum sprengelii, also species from the second group are present. The relevés from these columns all originate from SEC florulae, viz. the Northern Mittelgebirge, Denmark, and Mittelgebirge/Alpenvorland florulae (ssu. Haveman et al. 2016).

Ecologically, the relevés can be divided in two groups. The first group is differentiated by Acer campestre, Cornus sanguinea, and to a lesser extent Lonicera xylosteum and Rhamnus cathartica (column 1-2, and 18-21). They represent the bramble-rich Prunetalia scrubs on soils on slightly more nutrient and base rich soils (Weber 1999). The second group (column 3-17) is not positively characterised by one or more species, although Betula pendula and Salix aurita are almost restricted to this group; however, they only have a low frequency in the table. This group represents the bramble scrubs on the more nutrient and base poor soils.

In Table 1, three of the associations from literature are divided over different groups. The most obvious example is the Pruno-Rubetum vestiti (incl. Corno-Rubetum vestiti Haveman \& De Ronde in Haveman et al. 2017), which is divided over two geographically defined groups, viz. group A and C. Both the Pruno-Rubetum elegantispinosi and the Pruno-Rubetum radulae are split up over the two different ecological groups, as was done already in the original works by distinguishing different subassociations.

From Table 2 it is clear that the differential Rubus species from Table 1 coincide with (a selection of) indicator species of the territories as distinguished by Haveman et al. (2016). There exists an obvious difference between the groups of differential species in Table 2. The differential species of group A and $\mathrm{B}$ are for a large proportion (60\% and $33 \%$ respectively) indicated as indicator species for the NWC territory by Haveman et al. (2016), whereas $57 \%$ of the differential species of group $\mathrm{C}$ are assigned to the SEC territory by these authors. Indicator species for the BI territory are only present in the in the indicator species belonging to groups A and B.

\section{Discussion}

\section{Phytosociological considerations}

It can be concluded from the presented results that the main gradient in the data is a geographical one, predominantly characterised by bramble species. A second, ecological gradient, is less prominent, and characterised by phanerogam species. However, this is based on a dataset which is not fully covering the complete study area and for a part not 
Table 1 Summarising synoptic table of Rubus scrub associations of the Prunetalia spinosae (heavily shortened)

column

(sub-)association

source

group

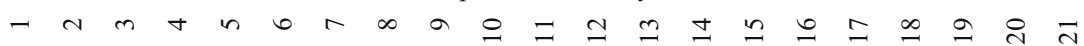

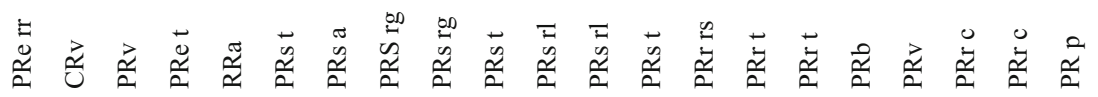

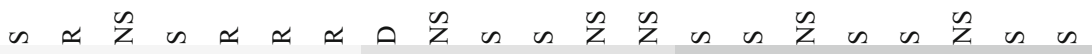

$\mathrm{B}$

Differential species group A

Rubus winteri

Rubus elegantispinosus

Rubus macrophyllus

Rubus lindleianus

Rubus geniculatus

Rubus umbrosus

Rubus raduloides

Rubus chloocladus

Rubus affinis

Rubus ulmifolius

Differential species group B

Rubus sprengelii

Rubus silvaticus

Rubus plicatus

Rubus nemoralis

Rubus platyacanthus

Rubus gratus

Ilex aquifolium

Differential species group $\mathrm{C}$

Rubus rudis

Rubus radula

Rubus montanus

Rubus nemoralis var.

agyrophyllus

Rubus hadracanthos

Rubus orthostachys

Rubus grabowskii

Ecological differential species

Acer campestre

Cornus sanguinea

Lonicera xylosteum

Rhamnus cathartica

Betula pendula

Salix aurita

\begin{tabular}{|rrrrrrr|}
\hline II & 6 & II & III & & 3 & \\
V & 18 & & V & 10 & 10 & \\
II & 24 & & I & & 33 & 25 \\
II & & II & III & & 21 & 31 \\
& 22 & II & & & 26 & 10 \\
& 6 & & & 30 & 15 & 8 \\
V & 4 & & & & 3 & \\
& & II & & & 3 & 2 \\
& & & & 87 & 14 & 8 \\
& & & & 17 & & \\
& 20 & & & 17
\end{tabular}

Other syntaxonomically important Rubus species

Rubus vestitus

Rubus langei

Rubus procerus

Rubus vadalis

Rubus thalassarctos

Rubus ceratifolius
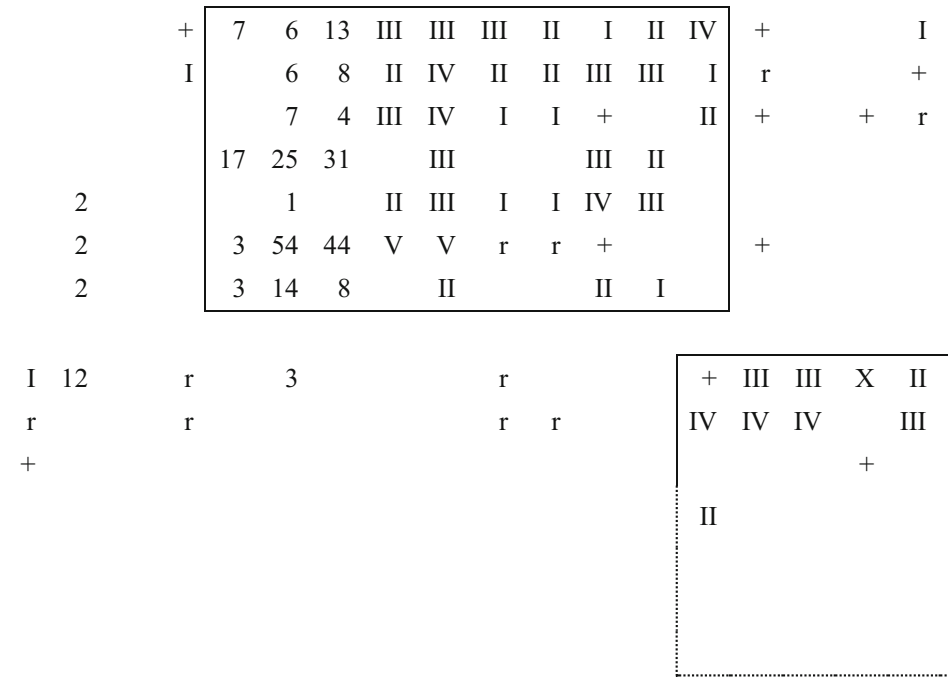

r

r r
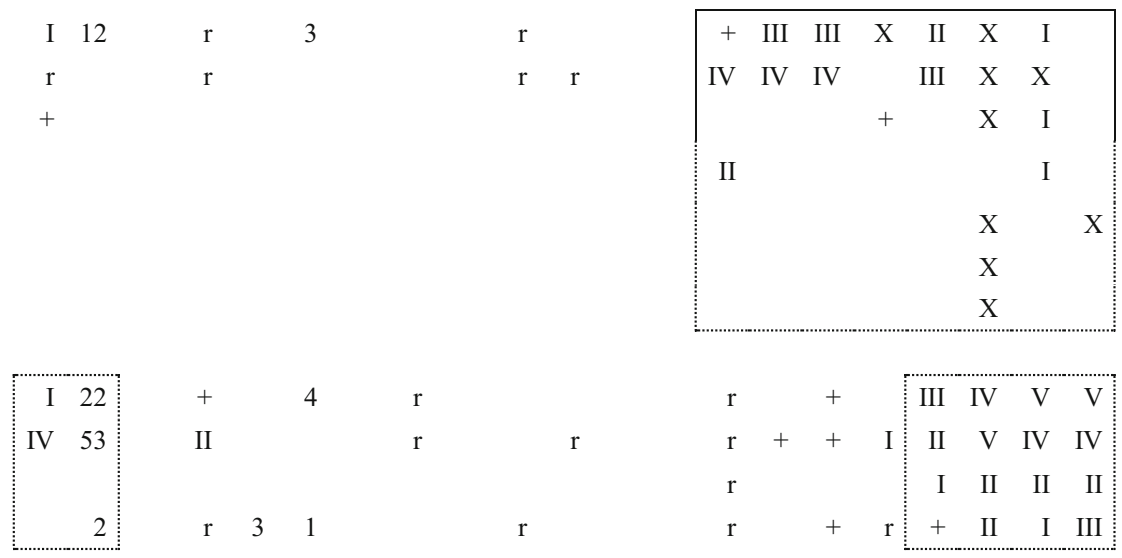

$+2$

\begin{tabular}{|c|c|c|c|c|c|c|c|}
\hline \multirow{2}{*}{\multicolumn{2}{|c|}{ II 10}} & 8 & 19 & II & & & \\
\hline & & 1 & 4 & & II & + & I \\
\hline
\end{tabular}

I 
Table 1 (continued)

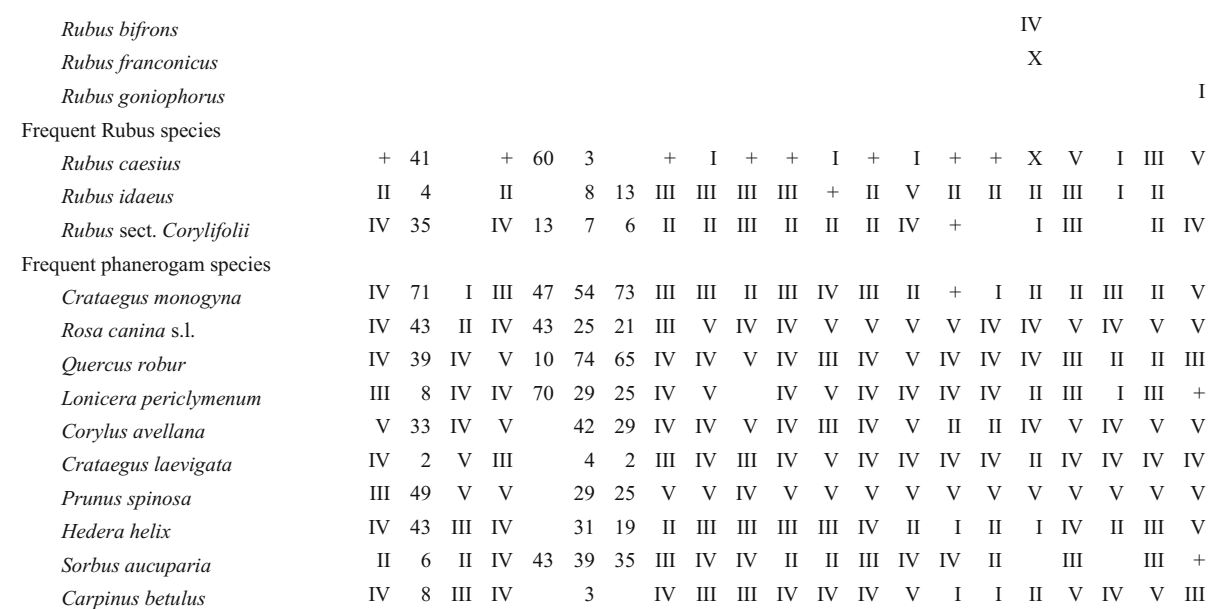

Each column represents a synoptic table of a (subassociation) from the following literature sources: NS = Pflanzengesellschaften Niedersachsens (Preising et al. 2003); $\mathrm{R}=$ Revisie Vegetatie van Nederland (Haveman et al. 2017); $\mathrm{S}=$ Synopsis (Weber 1999). The following (sub-)associations are included: $\mathrm{CRv}=$ Corno-Rubetum vestiti; $\mathrm{PRb}=$ Pruno-Rubetum bifrontis; $\mathrm{PRe} \mathrm{rr}=$ Pruno-Rubetum elegantispinosi rubetosum raduloides; $\mathrm{PRe} \mathrm{t}=$ Pruno-Rubetum elegantispinosi typicum; PR p = Pruno-Rubetum proceri (= Pruno-Rubetum praecoci nom. Corr.); $\mathrm{PRr} \mathrm{c}=$ Pruno-Rubetum radulae cornetosum; $\mathrm{PRr} \mathrm{rs}=$ Pruno-Rubetum radulae rubetosum sprengelii; $\mathrm{PRr} \mathrm{t}=$ Pruno-Rubetum radulae typicum; $\mathrm{PRs}$ a $=$ Pruno-Rubetum sprengelii alnetosum; $\mathrm{PRs} \mathrm{t}=$ Pruno-Rubetum sprengelii typicum; $\mathrm{PRs} \mathrm{rg}=$ Pruno-Rubetum sprengelii rubetosum grati $; \mathrm{PRs} \mathrm{rl}=$ Pruno-Rubetum sprengelii rubetosum lange $; \mathrm{PRv}=$ Pruno-Rubetum vestiti $\mathrm{RRa}=$ Roso rubiginosae-Rubetum affinis

taxonomically up to date. The data from the Netherlands is almost completely collected after 1995, and for a large part even between 2005 and 2017, and it covers large parts of the area in which brambles are present. The recent origin of the original relevés guarantees a bramble taxonomy which can meet present-day standards. The German data however are for a large part collected in the 1960's and 1970's, resulting in a serious under-recording of species, amongst which those of the highly critical sect. Corylifolii. The taxonomy of this section was cleared not earlier than the 1980's and 1990's and therefore several of its more common species are added post hoc in the Synopsis (Weber 1999) and the overview of Niedersachsen (Preising et al. 2003), both in the text and in the tables. This severely obscures a clear understanding of the species composition of these scrubs. Furthermore, the knowledge of the bramble scrubs in south Germany is only fragmentary, and data is only available from scattered locations (Oberdorfer and Müller 1992; Reif 1983; Reif 1985).

A problem of the used method is the unbalanced representation of associations in Table 1. One of the better-understood bramble communities of the Prunetalia is the Pruno-Rubetum sprengelii. It was described for Schleswig-Holstein by Weber (1967) in his classical study of the 'Knicks' (hedges), and later confirmed by Wittig (1976) for Westphalia, Rosskamp (1999) for Niedersachsen, and Haveman et al. (2014a) for the Netherlands. It was included in all three source publications for this paper, and as a result there are no less than seven columns in our table representing the Pruno-Rubetum sprengelii. Opposed to this, the Pruno-Rubetum bifrontis, which probably has a similar large distribution range (considering the distribution of $R$. bifrons, see Kurtto et al. 2010) and internal variation as the Pruno-Rubetum sprengelii, was only studied by Oberdorfer and Müller (1992) and Reif (1985) in south Germany, and only included in the Synopsis in one column. When interpreting Table 1, this disparity between the associations has to be taken into consideration. In fact, group B consists of German Pruno-Rubetum sprengelii columns completely, and can therefore be considered an artefact, induced by the method. Therefore, it can better be included in group A, together with the Dutch Pruno-Rubetum sprengelii, since the distribution areas of the characteristic species of both groups overlap partly, especially in the western part of the area of the Pruno-Rubetum sprengelii. Of course, better results would be obtained by a proper study of separate relevés of bramble scrubs, but at date, no electronic data from a wider region are available.

The division in a western group $(\mathrm{A}+\mathrm{B})$ and an eastern group (C) of communities supports the idea to distinguish two alliances in the Prunetalia to separate the bramble scrubs of northwest and central Europe, viz. the Pruno-Rubion sprengelii for northwest Europe and the German Plain, and the Pruno-Rubion radulae for central Europe, as was suggested by Haveman et al. (2017). In both alliances, associations can be distinguished following different lines of reasoning. The first one follows Weber (e.g. 1999), who distinguishes many associations, solely on the basis of the occurrence of bramble species. A second line of reasoning was followed by Oberdorfer and Müller (1992), who distinguished only one bramble-rich Prunetalia association, the Rubo fruticosi-Prunetum spinosae (a phantom name), with many regional races based on the occurrence of bramble species. Their argument for this practice is the problematic identification of the microspecies of the Rubus fruticosus aggregate, 
Table 2 Coincidence between Rubus species in bramble scrubs of the Prunetalia spinosae and their indication for phytogeographical regions

\begin{tabular}{|l|l|l|}
\hline & Differential species & Florula / Territory \\
\hline & & \\
\hline Group A & \\
\hline & Rubus winteri & WB \\
\hline & Rubus elegantispinosus & WB \\
\hline & Rubus macrophyllus & NWC \\
\hline & Rubus lindleianus & $\mathrm{BI}$ \\
\hline & Rubus geniculatus & $\mathrm{NL}+\mathrm{WB}$ \\
\hline & Rubus umbrosus & $\mathrm{NWC}$ \\
\hline & Rubus raduloides & - \\
\hline & Rubus chloocladus & - \\
\hline & Rubus affinis & $\mathrm{NWC}$ \\
\hline & Rubus ulmifolius & $\mathrm{BI}$ \\
\hline Group B & \\
\hline & Rubus sprengelii & $\mathrm{NWC}$ \\
\hline & Rubus silvaticus & $\mathrm{NWC}$ \\
\hline & Rubus plicatus & $\mathrm{C}$ \\
\hline & Rubus nemoralis & $\mathrm{BI}$ \\
\hline & Rubus platyacanthus & - \\
\hline & Rubus gratus & $\mathrm{C}$ \\
\hline Group C & \\
\hline & Rubus rudis & $\mathrm{C}$ \\
\hline & Rubus radula & $\mathrm{DK}$ \\
\hline & Rubus montanus & $\mathrm{C}$ \\
\hline & Rubus nemoralis var. agyrophyllus & - \\
\hline & Rubus hadracanthos & $\mathrm{NM}$ \\
\hline & Rubus orthostachys & $\mathrm{EM}+\mathrm{NM}$ \\
\hline & Rubus grabowskii & $\mathrm{SEC}$ \\
\hline
\end{tabular}

Differential species $=$ differential species from Table 1. Florula $/$ Territory $=$ indicator in the Florulae and Territories as described by Haveman et al. (2016). Abbreviations and colours territories: $\mathrm{BI}=$ orange $=$ British Isles territory; $\mathrm{NWC}=$ green $=$ Northwest Continent territory; $\mathrm{SEC}=\mathrm{blue}=$ Southeast Continent territory; $\mathrm{C}=\mathrm{NWC}+\mathrm{SEC}$. Abbreviations florulae: DK $=$ Denmark; $\mathrm{EM}=$ Eastern Mittelgebirge; $\mathrm{NL}=\mathrm{North}$ Netherlands + South Netherlands; NM = Northern Mittelgebirge; WB = Westfälische Bucht

and their (supposed) capricious occurrence in the scrubs. A third line of reasoning was followed by Haveman et al. (2017). The problem in the two first approaches is that the ecological information is obscured, due to the overrating of the value of regionally distributed species with similar ecological profiles by Weber, and the disregard of the ecology of the occurring Rubus species by Oberdorfer and Müller. Therefore, Haveman et al. (2017) distinguished three associations for the Netherlands, based on the complete species composition of the communities (including the Rubus species), and they concluded that all three associations had clear ecological as well as physio-geographical profiles, and all three associations have their own Rubus character species. The Corno sanguinei-Rubetum vestiti is found on nutrient and base rich soils on loess and old river clays in the southernmost part of the country as well as along the large rivers. It is the western vicariant of the Pruno-Rubetum vestiti (see column 2, Table 1). The Pruno-Rubetum sprengelii is found on less nutrient and base rich soils, especially in brook valleys north of the large rivers, in the region adjacent to the German Plain, the classical region of the association. The division in these two associations was based also on the distribution of the ecological differential species in Table 1, which are also occurring in the synoptic table in the Synopsis (Weber 1999). A third Dutch association, the Roso rubiginosae-Rubetum affinis Haveman \& De Ronde in Haveman et al. 2017 (column 5, Table 1) is found on superficially decalcified dune sands along the North-Sea and Wadden-Sea coast, where it replaces scrubs of the Salicion arenariae Tüxen ex Passarge 1963 in the succession. Contrary to the former two associations, the RosoRubetum affinis is confined to more natural landscapes.

\section{An evolutionary background?}

For the understanding of the causes of the differences in species composition of the bramble scrubs in central and 
northwest Europe, it is necessary to realise that most bramble species are (very) young neospecies (ssu. Levin 2000) with unsaturated distribution areas (Matzke-Hajek 1997; Weber 1981b). Contrary to most plant species in Europe, the agamospecies of Rubus subgen. Rubus largely evolved after the retreat of the ice sheets at the end of the Pleistocene period (Gustafsson 1943; Sochor et al. 2015). According to MatzkeHajek (1997), most Rubus apomicts in Europe are still in the first phase of expansion after their evolution, contrary to the large bulk of the European flora, which experienced one or more cycles of range contraction and expansion as the result of (inter alia) large scale climatic changes. This process of range contraction and expansion causes a large-scale resorting of species, and current plant communities developed in a process of competition between (re)colonising species which not necessarily evolved together.

Gustafsson (1943) hypothesised that apomixis in Rubus is the result of hybridisation events between (now probably extinct) ancestral species and polyploidisation after the large Pleistocene climate changes. Matzke-Hajek (1997) postulated that speciation and range expansion of the young (apomictic)
Rubus species have taken place in man-made landscapes. Broad-scale molecular study of Rubus species in Europe (Sochor et al. 2015) largely confirmed both these hypotheses: the European apomictic brambles probably originated from only six ancestral species, amongst which $R$. ulmifolius and $R$. canescens. After the retreat of the Pleistocene ice sheets, R. ulmifolius migrated from the Atlantic-Mediterranean area northwards along the Atlantic coast, whereas $R$. canescens migrated from the eastern Mediterranean area to the north along more eastern pathways. Both species formed hybrid swarms with other sexual species, especially with sexual representatives of the series Glandulosi and Rubus caesius, and these hybrids (partly) stabilised after polyploidisation as apomictic lineages. As was shown by Haveman et al. (2016), the different origins of the Rubus floras in northwest and central Europe are reflected in their respective speciespools. In the NWC territory Rubus flora, the ulmifolius-haplotype is dominant over the canescens-haplotype (Haveman et al. 2016; Sochor et al. 2015), and in the Rubus flora in the SEC territory the canescens-haplotype is dominant over the ulmifolius-haplotype. Other haplotypes,

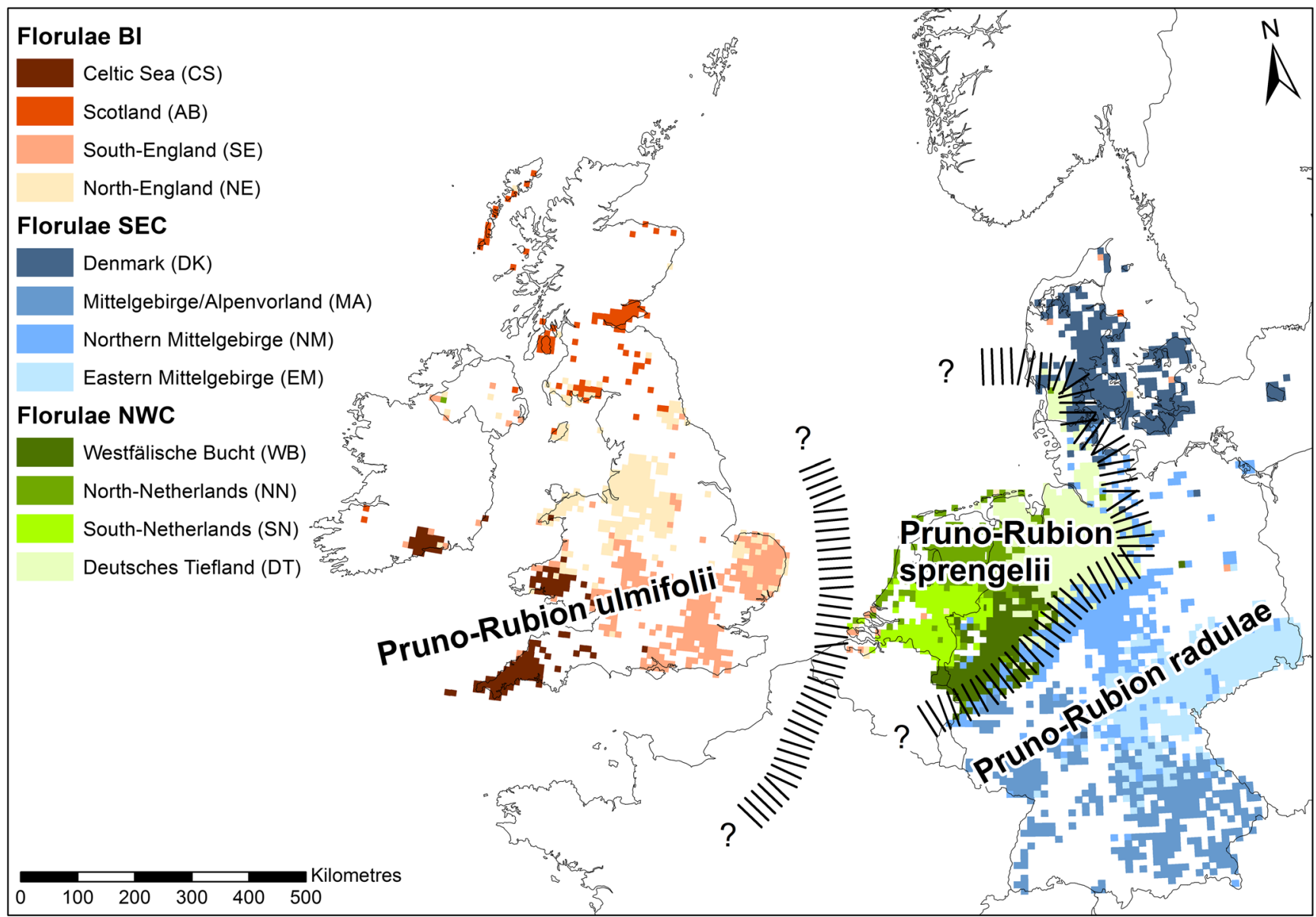

Fig. 1 Hypothesised distribution areas of the Pruno-Rubion ulmifolii, Pruno-Rubion sprengelii, and Pruno-Rubion radulae. The border areas between the alliances are based on the Rubus territories published by Haveman et al. (2017): red = British Isles territory; green = Northwest
Continent territory; blue $=$ Southeast Continent territory. The different shades of the colours are the florulae as described by these authors (see legend for explanation) 
like the glandulosi-haplotype and the suberecti-haplotype, are more evenly distributed over the territories.

Haveman et al. (2016) argued that there is a gross difference in ecology between the NWC and SEC territory Rubus floras as a result of ' inherited ecology': the individual species in the apomict swarms inherited the ecology from their ancestors. The ecology of R.ulmifolius and R. canescens can be characterised as 'warm and humid' and 'warm and dry' respectively (Haveman et al., 2016). Moreover, R. canescens is more or less basiphillous, whereas R. ulmifolius seems to be less demanding in respect to soil $\mathrm{pH}$ (Weber 1995). From our results, it shows that there exists a strong coincidence between the two Rubus territories and the two alliances as here distinguished, and we therefore conclude that both alliances too differ ecologically: the Pruno-Rubion sprengelii is characteristic for more humid, and probably less base-rich conditions than the Pruno-Rubion radulae. However, the current distribution areas of these alliances did not arise as a result of this ecology (i.e. in a process of competition between their respective characteristic species), but as a result of historical evolutionary processes. What we observe is the development of the vegetation in a very early stage of the evolution of the genus, where most species are very young and still have unsaturated distribution areas. Therefore we argue here that, although both the species and the vegetation types can be characterised in ecological terms, the underlying process that causes the difference in species composition of the two alliances has to be sought in the separate lines of development of the Rubus floras in northwest and central Europe.

The strong coincidence between the Pruno-Rubion radulae and Pruno-Rubion sprengelii on the one hand, and the NWC and SEC territories on the other, makes it possible to give a preliminary outline of the distribution areas of both alliances (Fig. 1). In this figure, also the tentative distribution of the Pruno-Rubion ulmifolii in north-west Europe is given, on the basis of the area of the BI territory (Haveman et al. 2016). Especially in the south, the exact borders between the alliances are not clear (indicated by question marks in the Figure). This is mainly caused by the largely unknown bramble flora of France (Kurtto et al. 2010), a country with a very rich bramble flora right in the centre of diversity of the genus in Europe (Matzke-Hajek 1997). Another problem is the northern border of the Pruno-Rubion ulmifolii, which generally is indicated as thermophilous. The Rubus scrubs of the hyperatlantic and cool parts of the BI territory, especially in north England and Scotland, are probably not belonging to this alliance, but their exact assignment is unclear.

Although the Pruno-Rubetum radulae and Pruno-Rubetum sprengelii are largely vicariant alliances, even from our table it is clear they are not completely separated. The PrunoRubetum radulae rubetosum sprengelii harbours species from both alliances, and represents a transitional community in the border area between both groups of associations.
Management and ecology of bramble scrubs

For the management of bramble rich Prunetalia scrubs, it is useful to differentiate between ruricolous and silvicolous scrubs (Weber 1999; Weber 2003). Silvicolous scrubs are formed by species adapted to the tempered microclimate of woodlands, characteristic for clear cuts, woodland edges and other gaps in the canopy. Ruricolous scrubs on the contrary, are formed by species adapted to the harsher microclimate outside the direct influence of woodlands, like hedgerows and other scrubs in the man-made (agricultural) landscape. Both the Pruno-Rubion radulae and the Pruno-Rubion sprengelii are typical ruricolous scrub types, in their existence dependent on management. Huwer and Wittig (2012) analysed the change of the species composition of bramblerich Prunetalia hedges in the Westphalian Basin between the 1970's and 2010, and they concluded the species composition changed significantly due to abandonment (or change from the traditional management) and hypertrophication. Establishment of trees in the hedgerows following abandonment caused a decrease of the light-demanding shrubs, and hypertrophication led to the replacement of species of woodland remnants in the field layer by ruderals, like Urtica dioica. Nitrophilous species can eventually even replace Rubus species (Loos 2008; Weber 1997). An important, and more disastrous factor in the decline of mesophilous Rubus-rich scrubs has been the large-scale and complete clearing of hedgerows in large parts of Germany (Weber 2003) and the Netherlands (Haveman 2017). Whereas intensification can lead to losses of bramble-rich communities, abandonment of formerly used (agricultural) areas can give opportunities for the expansion of bramble scrubs (Haveman 2017).

Silvicolous bramble scrubs are placed in the Sambucetalia racemosae Oberdorfer 1957, and more particular in the recently validated Athyrio felicis-feminae-Rubion idaei Passarge ex Haveman et al., 2014b. These scrubs are less dependent on human interventions than the scrubs of the Pruno-Rubion radulae and Pruno-Rubion sprengelii. Their typical Rubus flora is formed by the forest-dwelling glandular species of the series Glandulosi and Hystrix (like Rubus bellardii and Rubus hirtus agg.), which have their optimum in ancient woodland remnants. These species seem to form a rather independent evolutionary line (Sochor et al. 2015), and they would probably dominate the landscape of central and north-west Europe if man wouldn't have cleared large areas, giving rise to the large hybrid-swarms of $R$. ulmifolius and $R$. canescens. AthyrioRubion scrubs can develop even in small, natural gaps in the canopy, but typically they occur in vast areas after large-scale felling of woodlands, especially in colline and low-montane regions. Since these scrubs are among the least understood plant communities in Europe (Weber 1998a), very little is known about changes over time, or the influence of different management regimes or climate changes. 


\section{Concluding remarks}

As shown in the previous paragraphs, the phytosociological patterns in Rubus scrubs of the Prunetalia in northwest and central Europe coincide with the phytogeographical patterns in the genus Rubus, and we argue that, although both species as well as the vegetation types differ ecologically, phytogeographical as well as phytosociological patterns are caused by evolutionary processes.

It is obvious that the distinction of two alliances instead of one Pruno-Rubion radulae raises the need of new names for several earlier described associations, because an association name can only used once, in one particular alliance. An example is the Pruno-Rubetum vestiti in the Dutch National Vegetation Classification (Haveman et al. 1999), which in the recently published revision had to be renamed to Corno sanguinei-Rubetum vestiti (Haveman et al. 2017) because the original name relates to an association of the Pruno-Rubion radulae, and the Dutch association should be assigned to the Pruno-Rubion sprengelii. The same would apply to the 'Pruno-Rubetum vestiti' published in the overview of Niedersachsen (Preising et al. 2003), and similar problems may arise when the species composition of scrubs with established names are compared to our Table 1.

As final comment we would like to stress the need for more detailed phytosociological studies of bramble scrubs in areas where these community-types are under-recorded, and systems which are largely overlooked (like the Rubus-scrubs of woodland-clearings of the Athyrio-Rubion idaei). We think this paper opens promising perspectives of the insights that can be gained when studying this intriguing group. A next step, which also would promote international batosociological cooperation, would be to build an international Rubus scrub plot database, to analyse phytosociological and other patterns in more detail.

\section{Compliance with ethical standards}

Conflict of interest The authors declare that they have no conflict of interest.

Open Access This article is distributed under the terms of the Creative Commons Attribution 4.0 International License (http:// creativecommons.org/licenses/by/4.0/), which permits unrestricted use, distribution, and reproduction in any medium, provided you give appropriate credit to the original author(s) and the source, provide a link to the Creative Commons license, and indicate if changes were made.

Publisher's note Springer Nature remains neutral with regard to jurisdictional claims in published maps and institutional affiliations.

\section{References}

Dierschke H (1994) Pflanzensoziologie: Grundlagen und Methoden. In: UTB-Serie. Ulmer, Stuttgart
Gustafsson $\AA$ (1942) The origin and properties of the European blackberry flora. Hereditas 28:249-277

Gustafsson $\AA$ (1943) The Genesis of the European Blackberry Flora Lunds Univ Aarskr 39:1-199

Haveman R (2017) Concealed diversity. Taxonomical, phytogeographical and phytosociological notes on brambles (Rubus L. subgen. Rubus) in north-West Europe. Wageningen University

Haveman R, Schaminée JHJ, Weeda EJ (1999) Rhamno-Prunetea. In: Stortelder AHF, Schaminée JHJ, Hommel PWFM (eds) De vegetatie van Nederland. Deel 5. Plantengemeenschappen van ruigten, struwelen en bossen, vol, vol 5. Opulus Press, Uppsala, Leiden, pp 121-164

Haveman R, De Ronde I, Bijlsma RJ, Schaminée JHJ (2014a) Systematic randomised sampling along three landscape transects in the Netherlands reveals the geographically structured variation in Rubus scrubs. Phytocoenologia 44:31-44. https://doi.org/10.1127/ 0340-269X/2013/0043-0564

Haveman R, De Ronde I, Weeda EJ (2014b) Ecologie, verspreiding en syntaxonomie van Nederlandse struwelen. II Bramenrijke kapvlaktebegroeiingen Stratiotes 46:5-40

Haveman R, Bijlsma RJ, De Ronde I, Schaminée JHJ (2016) Capricious, or tied to history's apron strings? Floristic regions in NorthwestEuropean brambles (Rubus subgenus Rubus, Rosaceae). J Biogeogr 43:1360-1371. https://doi.org/10.1111/jbi.12704

Haveman R, De Ronde I, Schaminée JHJ (2017) Rhamno-Prunetea Stratiotes 50/51:138-160

Huwer A, Wittig R (2012) Changes in the species composition of hedgerows in the Westphalian Basin over a thirty-five-year period Tuexenia 32:31-53

Kurtto A, Weber HE, Lampinen R, Sennikov AN (2010) Atlas Florae Europaeae. Distribution of vascular plants in Europe. Rosaceae (Rubus). The Committee for Mapping the Flora of Europe \& Societas Biologica Fennica Vanamo, Helsinki

Levin DA (2000) The origin, expansion, and demise of plant species. In: Oxford University press. New York, Oxford

Loos GH (2008) Pflanzengeographische Beiträge zur chorologischen, taxonomischen und naturschutzfachlichen Bewertung der Sippendiversität agamospermer (apomiktischer) Blütenpflanzenkomplexe: das Beispiel Rubus subgenus Rubus (Rosaceae) vol Doktor. Fakultät XVII Geowissenschaften. RuhrUniversität, Bochum

Matzke-Hajek G (1997) Zur Evolution und Ausbreitung apomiktischer Rubus-Arten (Rosaceae) in Offenland-Ökosystemen Bull Geobot Inst ETH 63:33-44

Mucina L et al (2016) Vegetation of Europe: hierarchical floristic classification system of vascular plant, bryophyte, lichen, and algal communities. Appl Veg Sci 19:3-264. https://doi.org/10.1111/avsc. 12257

Oberdorfer E, Müller T (1992) Prunetalia spinosae. In: Oberdorfer E (ed) Süddeutsche Pflanzengesellschaften. Ed. 2.4. G. Fischer, Jena, Stuttgart \& New York, pp 82-106, tables, pp 145-175

Preising E, Weber HE, Vahle H-C (2003) Die Pflanzengesellschaften Niedersachsens - Bestandsentwicklung, Gefährdung und Schutzprobleme. Wälder und Gebüsche vol Heft 20/2. Niedersächsisches Landesamt für Ökologie - Abt. Naturschutz, Hildesheim

Reif A (1983) Nordbayerische Heckengesellschaften Hoppea 41:3-205

Reif A (1985) Flora und Vegetation der Hecken des Hinteren und Südlichen Bayerischen Wäldes Hoppea 44:179-276

Rosskamp T (1999) Die Vegetation der Feld- und Wallhecken in Niedersachsen. Galunder-Verlag, Wiehl

Royer J-M (2013) Étude phytosociologique de quelques ronciers péri- et intraforestiers des environs de Chaumont Bull Soc Sci Nat Arch HtMarne 21:10-20

Sochor M, Vašut RJ, Sharbel TF, Trávníček B (2015) How just a few makes a lot: speciation via reticulation and apomixis on example of 
European brambles (Rubus subgen. Rubus, Rosaceae). Mol Phylogenet Evol 89:13-27

Weber HE (1967) Über die Vegetation der Knicks in Schleswig-Holstein. Arbeitsgemeischaft für Floristik in Schleswig-Holstein und Hamburg, Kiel

Weber HE (1974) Eine neue Gebüschgesellschaft in Nordwestdeutschland und Gedanken zur Neugliederung der Rhamno-Prunetea. Osnabr Naturwiss Mitt 3:143-150

Weber HE (1981a) Kritische Gattungen als Problem für die Syntaxonomie der Rhamno-Prunetea in Mitteleuropa. In: Dierschke H (ed) Syntaxonomie. Berichte der Internationalen Symposien der Internationalen Vereinigung für Vegetationskunde. J. Cramer, Vaduz, pp 477-496

Weber, HE (1981b) Revision de Sektion Corylifolii (Gattung Rubus, Rosaceae) in Skandinavien und im Nördlichen Mitteleuropa Verlag Paul Parey, Hamburg, Berlin

Weber HE (1990) Übersicht über die Brombeergebüsche der PteridioRubetalia (Franguletea) und Prunetalia (Rhamno-Prunetea) in Westdeutschland mit grundsätzlichen Bemerkungen zur Bedeutung der Vegetationsstruktur Ber Reinhold-Tüxen-Ges 2:91119

Weber HE (1995) Rubus L. In: Conert HJ, Jäger EJ, Kadereit JW, Schultze-Motel W, Wagenitz G, Weber HE (eds) Gustav Hegi
Illustrierte Flora von Mitteleuropa. Band IV. Teil 2A. Spermatophyta: Angiospermae: Dicotyledones 2(2), vol IV. Teil 2A. Blackwell, Berlin, pp 284-595

Weber HE (1997) Hecken und Gebüsche in den Kulturlandschaften Europas - Pflanzensoziologische Dokumentation als Basis für Schutzmassnahmen Ber Reinhold-Tüxen-Ges 9:75-106

Weber HE (1998a) Franguletea (H1). Faulbaum-Gebüsche Synopsis der Pflanzengesellschaften Deutschlands 4:3-86

Weber HE (1998b) Outline of the vegetation of scrubs and hedges in the temperate and boreal zone of Europe Deutschlands. Itiner Geobot 11:85-120

Weber HE (1999) Rhamno-Prunetea (H2A). Schlehen- und Traubenholunder-Gebüsche Synopsis der Pflanzengesellschaften Deutschlands 5:3-108

Weber HE (2003) Gebüsche, Hecken, Krautsäume. In: Ökosysteme Mitteleuropas aus geobotanischer Sicht. Ulmer, Stuttgart

Wittig R (1976) Die Gebüsch- und Saumgesellschaften der Wallhecken in der Westfälischen Bucht Abh Westf Mus Naturk 38:1-78

Wittig R (1977) Rubus-Arten in Wallhecken als Zeigerpflanzen der potentiellen natürlichen Vegetation Mitt Flor-soz Arbeitsgem NF 19/20:353-355 